\title{
KOMUNIKASI PERSUASIF PROGRAM PEMBINAAN MUALAF PADA LEMBAGA DAKWAH MUHTADIN MASJID AL FALAH SURABAYA
}

\author{
Sri Wahyuni \\ STID Al-Hadid, Surabaya \\ eswe.wahyuni87@gmail.com
}

\begin{abstract}
Abstrak: Problematika pemahaman terhadap agama Islam senantiasa mengiringi langkah mualaf setelah masuk Islam. Di antaranya mualaf Muhtadin Masjid Al Falah Surabaya. Persoalan tersebut antara lain mengenai keyakinan terhadap Tuhan sebagai Zat Pencipta, presepsi negatif mualaf terhadap Islam yang identik dengan teroris, poligami dan sebagainya. Sudah menjadi kewajiban seorang muslim untuk meluruskan pemahaman tersebut agar mualaf bisa memahami Islam dengan benar. Hal tersebut sebagaimana yang dilakukan oleh Lembaga Muhtadin dalam program pembinaan mualaf dengan menggunakan komunikasi persuasif, sehingga dai mampu menarik perhatian mad'uw, pesan mudah dipahami, dimengerti, selanjutnya mualaf dapat menjalankan. Studi ini menjelaskan proses komunikasi persuasif program pembinaan mualaf lembaga dakwah Muhtadin Masjid Al Falah Surabaya. Studi ini menggunakan teori prinsip komunikasi persuasif menurut De Vito, melalui pendekatan kualitatif deskriptif, data didapatkan dari wawancara, dokumentasi serta pengamatan. Hasilnya menunjukkan bahwa Lembaga Muhtadin: Pertama, memenuhi prinsip partisipasi khalayak yaitu instruktur menggunakan metode diskusi dan tanya jawab pada saat forum serta bahan diskusi sesuai dengan kebutuhan mualaf. Kedua, memenuhi prinsip Inokulasi yaitu instruktur tidak lantas menyanggah dan menjawab pertanyaan mualaf secara langsung, namun memberikan argumentasi, mualaf menemukan jawaban sendiri. Ketiga, memenuhi prinsip pemaparan selektif artinya anggota mualaf aktif mencari informasi yang mendukung kepercayan mereka dan menghindari informasi yang bertentangan dengan kepercayaan mereka.
\end{abstract}

Kata Kunci: komunikasi persuasif, pembinaan mualaf, akidah.

\begin{abstract}
Problems on understanding Islam are always following the steps of a muallaf after converting to Islam. It also happens to muallaf of Muhtadin in the mosque Al Falah Surabaya. The problems are about the belief towards Allah The Creator, negative perception from muallaf about Islam which is identical and related to terrorism, poligamy, and so forth. It is obligatory for Moslems to clarify those understandings in order that a muallaf understands Islam correctly. It is what the institution of Muhtadin in the program of cultivating muallaf. This institution applies persuasive communcation so enables a dai to attract the attention of mad'uw. The message of da'wah can be easily understood and muallaf can likely conduct it. This study explains the process of persuasive communication in the program of cultivating muallaf in the mosque Al Falah Surabaya. It uses De Vito's theory of persuasive communication principles. It uses descriptive qualitative approach. The data were obtained from interview, documentation and observation. The result indicates that the institution of Muhtadin: first, this institution fulfils the principle of public participation; the instructor applies methods of discussion and question and answer during the forum and the material of discussion is appropriate
\end{abstract}


for the need of muallaf. Second, it fulfils the inoculation principle; the instructor does not directly rebut and answer muallaf's question. The instructor gives argumentation and lets muallaf find the answer of problem. Third, the institution fulfils the principle of selective explanation; muallaf actively find the information supporting their belief and avoid information against their belief.

Keywords: persuasive communication, cultivating muallaf, aqidah/belief

\section{Pendahuluan}

Mualaf adalah orang yang baru masuk Islam. Pertumbuhan mualaf di Indonesia terus naik dari tahun ke tahun. Berdasarkan data dari Mualaf Center Indonesia, pada tahun 2016 setidaknya ada 2.854 orang masuk Islamdi seluruh Indonesia. Jumlah mualaf tertinggi ada pada tahun 2006, dan sempat melandai pada tahun 2007 sampai dengan 2009. Namun pertumbuhan jumlah mualaf kembali naik pada tahun 2010, dan terus naik pada tahun 2011, 2012 sampai dengan sekarang angkanya terus naik. Paling tidak dalam lima tahun ke belakang sudah lebih dari 10 ribu orang masuk Islam sejak dihitung dari $2011{ }^{1}$ Mualaf adalah salah satu bagian dari objek dakwah yang memerlukan bimbingan dan pembinaan dalam memahami agama Islam. Mualaf adalah orang yang mengalami konversi agama, perpindahan agama seringkali dirasakan sebagai sebuah proses yang sangat sulit bagi mualaf. Mualaf diharapkan dapat meninggalkan seluruh nilai dan ajaran agama sebelumnya dan memulai memahami ajaran agama barunya. Seseorang yang memiliki keimanan dan keyakinan yang

1 Republika,"Lima Tahun Terakhir, Ada 10 ribu Orang Masuk Islam," Repubika.co.id, diakses 9 Mei 2018, http://republika.co.id/berita/dunia-islam/islamnusantara/17/02/01/okpetz394-lima-tahun-terakhirada-10-ribu-orang-masuk-islam. kokoh disebabkan pemahaman terhadap ajaran agama yang kuat, sehingga menjalankan perintah agama dengan benar dan tepat.

Problematika persoalan pemahaman terhadap agama Islam senantiasa mengiringi langkah mualaf setelah masuk Islam diantaranya adalah sinkritisme agama. ${ }^{2}$ Selain itu hasil penelitian yang dilakukan oleh Titian Hakiki dan Rudi Cahyono menyatakan bahwa pemahaman mualaf terhadap kepercayaan Tuhan ada beberapa variasi. Ada yang memaknai bahwa Tuhan adalah entitas tunggal, Tuhan yang Maha Esa ada pula yang memaknai Zat yang mengendalikan hidup manusia, Zat yang Maha Tahu dan seterusnya. Sedangkan pemahaman mualaf terhadap ajaran Islam juga ada beberapa variasi, ada yang merasa bahwa dirinya masih sebatas pada level mempercayai Allah saja, dan belum dapat meyakini Allah dengan sungguhsungguh. Sedangkan, ada yang belum dapat mempercayai tentang alam gaib, terutama tentang makhluk gaib khususnya jin dan setan. $^{3}$

\footnotetext{
2 Ramlah Hakim, "Pola Pembinaan Mualaf di Kabupaten Sidrap Provinsi Sulawesi Selatan," Al-Qalam, Vol. 19, No.1, (Juni 2013): 93.

3 Titian Hakiki, Rudi Cahyono, "Komitmen Beragama pada Muallaf (Studi Kasus pada Muallaf Usia Dewasa)," Jurnal Psikologi Klinis dan Kesehatan Mental, Vol. 4. No. 1 (April 2015), 21.
} 
Dengan kondisi persoalan pemahaman yang dialami mualaf seperti paparan di atas, sehingga kewajiban bagi setiap muslim dan muslimah untuk meluruskan pemahaman mereka agar mereka bisa memahami ajaran agama Islam dengan benar. Setiap muslim wajib memperhatikan semua sikap, tingkah laku dan cara berkomunikasi dalam berdakwah sesuai dengan nilai dan ajaran agama Islam. Sesuai dengan firman Allah dalam surah Annahl ayat 125 yang berbunyi, "Serulah kepada jalan Tuhanmu dengan hikmah, dan nasehat-nasehat yang baik, dan bertukar fikiranlah dengan cara yang lebih baik. Sesungguhnya Tuhanmu lebih mengetahui siapa yang sesat dari jalan-Nya, dan Dia-lah yang mengetahui siapa yang terpimpin." Perkataan hikmah dalam bahasa komunikasi adalah pendekatan komunikasi yang dilakukan atas dasar persuasif. Mad'uw dalam menjalankan ajaran agama timbul atas keinginannya sendiri, tidak merasa terpaksa, konflik apalagi merasa tertekan. ${ }^{4}$

Tujuan pembinaan mualaf memberikan pemahaman dan menumbuhkan kesadaran dalam menjalankan ajaran agama sehingga mualaf bisa menerapkan ajaran agama tersebut dalam kehidupan sehari-hari baik dalam kehidupan bermasyarakat serta pembangunan pada umumnya. ${ }^{5}$ Untuk mencapai tujuan pembinaan mualaf maka

\footnotetext{
4 Toto tasmara, Komunikasi Dakwah, (Jakarta: Penerbit Gaya Media Pratama,1997),37-38.

5 Departemen Agama RI Ditjen Bimas Islam dan urusan Haji Proyek Peningkatan Tenaga Keagamaan "Pedoman Pembinaan Mualaf" diakses 16 Jnauari 2017, http://simbi.kemenag.go.id/pustaka/images/materibuk u/Pedoman\%20Pembinaan\%20Muallaf.pdf.
}

dibutuhkanlah komunikasi persuasif seorang pembina mualaf atau dai.

Komunikasi persuasif adalah komunikasi yang menekankan pada aspek kesadaran komunikan bukan didasarkan pada paksaan, ancaman dan intimidasi, sehingga komunikan mau merubah pendapat, sikap dan keyakinannya atas kemauan sendiri. ${ }^{6}$ Seorang dai dalam menyampaikan pesan dakwah kepada mad'uw agar tujuan komunikasi bisa tercapai, maka menggunakan komunikasi persuasif. Dai atau pembina mualaf harus mempertimbangkan psikologis mualaf terkait pemahaman dan pengetahuan yang dimiliki oleh mualaf. Sehingga dai mampu menarik perhatian para mad'uw karena pesan dakwah sesuai dengan kebutuhan mad'uw, pesan mudah dipahami, dimengerti dan tidak menyinggung perasaan mad'uw, sehingga mereka tertarik untuk mengikuti seruan dai dalam menerima dan melaksanakan ajaran Islam atas kemauan sendiri bukan didasarkan paksaan. Seperti yang pernah terjadi pada seorang mualaf yang melakukan dialog berdurasi 1,5 jam dengan kiai perihal konsep ketuhanan dalam Islam, sebelumnya mualaf sangat takut dengan Islam karena identik dengan teroris dan kekerasan. Setelah berdialog akhirnya berubah menganggap Islam sebuah agama yang tidak perlu untuk ditakuti, melainkan telah menjadi agama yang hak dan tidak ada yang lain kecuali Islam. ${ }^{7}$ Sehingga kemampuan komunikasi persuasif

\footnotetext{
6 Herdiyan Maulana dan Gumgum Gumelar, Psikologi Komunikasi dan Persuasi, (Jakarta: Akademia Permata 2013), 8.

7 Republika, "Dialog 1,5 Jam, Galih Putuskan Menjadi Muslim" republika.co.id, diakses 11 Mei 2018, http://khazanah.republika.co.id/berita/duniaislam/mualaf/15/01/30/nizjx5-dialog-15-jam-galihputuskan-menjadi-muslim.
} 
sangat penting dalam menyamakan pemahaman agar tercipta kesamaan makna atas dasar kesadaran bukan paksaan.

Seperti pada studi yang dilakukan oleh Nurhalima Tambunan dengan judul "Komunikasi Persuasif Majelis Tabligh Pimpinan Daerah Aisyiyah dalam Meningkatkan Akidah Islam di Kabupaten Karo Sumatera Utara", hasil studi tersebuti menyatakan komunikasi persuasif bisa meningkatkan jumlah jemaah dari waktu ke waktu, selain itu jemaah menganggap agama sebagai sesuatu yang penting untuk dijaga kemurnian dan kesuciannya. Serta pemahaman jemaah terhadap pengetahuan perihal tauhid, ibadah, akhlak, serta pengamalan agama jemaah mengalami peningkatan. ${ }^{8}$

Lembaga Dakwah Muhtadin Masjid Al Falah adalah bagian dari Yayasan Masjid Al Falah, Surabaya. Muhtadin adalah lembaga yang memberikan pelayanan, pembinaan dan pemberdayaan mualaf. ${ }^{9}$ Visi Muhtadin adalah menjadikan lembaga pelayanan pembinaan dan pemberdayaan Muhtadin menuju Islam kafah. ${ }^{10}$ Persoalan pemahaman terkait keyakinan terhadap tuhan dan ajaran Islam, juga didapati mualaf muhtadin setelah masuk Islam di antaranya adalah presepsi negatif mualaf terhadap Islam yang identik dengan poligami. Persoalan mualaf yang menyimpan keris. Persoalan status pernikahan mualaf setelah masuk Islam yang berbeda agama.

8 Nurhalima, “Komunikasi Persuasif Majelis Tabligh Pimpinan Daerah Aisyiyah dalam Meningkatkan Akidah Islam di Kabupaten Karo Sumatera Utara" (Tesis, IAIN, Medan, 2013), 67-68.

9 Djuari Sayaifuddin dan Rustanto setyawan dan Teguh Ismanto dkk, 35 Tahun Yayasan Masjid Al Falah
Persoalan yang dihadapi mualaf Lembaga Dakwah Muhtadin Masjid Al Falah perlu segera dibenahi agar tujuan Islam kafah tercapai, sejauh ini pembina mualaf Lembaga Dakwah Muhtadin ada indikasi atau gejalagejala menerapkan komunikasi persuasif dalam menjalankan program pembinaan mualaf. Semisal salah satu pembina mualaf pada Lembaga Dakwah Muhtadin Masjid Al Falah menuturkan, ketika berkomunikasi dalam rangka memecahkan persoalan status pernikahan mualaf setelah masuk Islam, tidak hitam putih artinya tidak lantas pernikahannya batal atau haram kemudian bercerai. Tetapi pembina mualaf memberikan solusi melihat kondisi situasi mualaf untuk mencari titik temu yang seimbang, misalnya memahami keadaan mualaf, termasuk orang yang berpengaruh ataukah tidak, jika orang yang berpengaruh sehingga bisa berpotensi untuk mengajak keluarga yang selainnya. ${ }^{11}$

Di dalam forum pembinaan mualaf, pembina mualaf senantiasa turut serta aktif melibatkan mualaf dalam berdiskusi bahkan tema pembahasan juga sesuai dan menjawab kebutuhan para mualaf. ${ }^{12}$ Hasil yang dicapai oleh pembina mualaf salah satunya ketika menerapkan komunikasi persuasif pada program pembinaan mualaf Lembaga Dakwah Muhtadin yaitu jumlah mualaf semakin banyak, bahwa tiap tahunnya Lembaga Dakwah Muhtadin membina 200 mualaf, keberadaan Iulusan Muhtadin bisa mencapai

Surabaya, (Surabaya: Yayasan Masjid Al Falah 2008), 196.

10 lbid.,198.

11 Anang Misabhul Munir, Wawancara oleh Penulis, Surabaya, 27 April 2017.

12 Ibid. 
180-200 orang tiap tahunnya. Sehingga lembaga Muhtadin di Masjid Al Falah memberikan kontribusi dan pelayanan secara optimal dalam melakukan pembinaan muallaf. ${ }^{13}$

Sehingga dengan paparan di atas, menarik sekali untuk mengkaji keberhasilan pembinaan mualaf Lembaga Dakwah Muhtadin Masjid Al Falah dalam menerapkan komunikasi persuasif. Namun karena keterbatasan waktu, studi ini hanya memaparkan komunikasi persuasif pembinaan mualaf dalam rangka membangkitkan kesadaran untuk menerima dan melaksankan ajaran Islam khususnya di bidang akidah. Studi terdahulu terkait dengan mualaf pernah dilakukan oleh Ramlah Hakim, ${ }^{14}$ Washilatur Rahmi, ${ }^{15}$ dan Tri Prasetyo Aprianto. ${ }^{16}$ Namun, studi-studi tersebut masih banyak memfokuskan pada pola pembinaan mualaf, bentuk komunikasi pembinaan mualaf dan strategi Komunikasi pembinaan mualaf, sedangkan tulisan ini lebih menekankan pada komunikasi persuasif pembinaan mualaf Lembaga Dakwah Muhtadin Masjid Al Falah Surabaya. Studi terdahulu dengan tema komunikasi persuasif ditemukan pada penelitian yaitu dilakukan Maike Desyafitri, ${ }^{17}$ dan Nurhalima Tambunan. ${ }^{18}$ Studi tersebut memaparkan penerapan komunikasi persuasif pada

13 Ahmad Zawawi Hamid, Wawancara oleh Penulis, Surabaya, 18 Januari dan 28 April 2017.

${ }^{14}$ Hakim, "Pola Pembinaan Mualaf.," 93.

15 Washilatur Rahmi, "Bentuk Komunikasi Pembinaan Muallaf Daarut Tauhid Jakarta," (Skripsi, Universitas islam Negeri Syarif Hidayatullah Jakarta 2008), 43.

16 Tri Prasetyo Aprianto, "Strategi Komunikasi Penyuluhan pada Pembinaan Muallaf di Yayasan ANNaba Center Sawah baru Ciputat," (Skripsi, Universitas islam Negeri Syarif Hidayatullah, Jakarta 2015), 67. komunitas Hijabers, jemaah tablig Kabupaten Karo Sumatera Utara, sehingga secara subjek komunikasi sudah berbeda dengan tulisan ini. Dua studi di atas yang membahas komunikasi persuasif setidaknya memberikan gambaran penerapan proses komunikasi persuasif. Studi ini bertujuan mengkaji penerapan komunikasi persuasif pada program pembinaan mualaf Muhtadin Masjid Al Falah di bidang akidah.

\section{Teori Komunikasi Persuasif}

Teori komunikasi persuasif yang digunakan sebagai unit analisis dalam studi ini menggunakan teori empat prinsip komunikasi persuasif menurut De Vito. Komunikasi persuasif adalah komunikasi yang mengajak seseorang agar sesuai dengan maksud komunikator atas dasar kesadaran, kerelaan, disertai perasaan senang dan tidak merasa terpaksa.

Dakwah sendiri memiliki arti secara etimologis adalah seruan, ajakan dan panggilan. Dakwah merupakan suatu proses penyampaian pesanpesan tertentu berupa ajakan atau seruan dengan tujuan orang lain memenuhi ajakan tersebut dengan cara bil hikmah. Pengertian hikmah seringkali diterjemahkan dalam pengertian bijaksana artinya pendekatan yang dilakukan kepada komunikan, sehingga komunikan melakukan sesuatu atas dasar

17 Maike Desyafitri, "Komunikasi Persuasif Komunitas Hijabers Pekanbaru dalam Merekrut Wanita Berjilbab di Kota Pekanbaru," JOM FISIP, Vol.2 No.1, (Februari 2015): 7.

18 Nurhalima, "Komunikasi Persuasif Majelis Tabligh Pimpinan Daerah Aisyiyah dalam Meningkatkan Akidah Islam di Kabupaten Karo Sumatera Utara" (Tesis, IAIN, Medan, 2013), 67-68. 
keinginannya sendiri, merasa tidak ada paksaan, konflik apalagi merasa tertekan. ${ }^{19}$ Dalam bahasa komunikasi pengertian bil hikmah adalah suatu metode pendekatan komunikasi yang dilakukan dasar persuasif dengan harapan agar komunikan dapat bersikap dan berbuat amal saleh sesuai dengan ajaran islam. ${ }^{20}$

Sehingga pemilihan teori komunikasi persuasif De Vito relevan digunakan dalam konteks dakwah karena dakwah sendiri memiliki arti seruan, ajakan dan panggilan dengan cara bil hikmah atau pendekatan komunikasi yang dilakukan dasar persuasif. Studi yang ingin diteliti terkait bagaimana upaya pembina mualaf memengaruhi pendapat, sikap, dan tindakan anggota mualaf di dalam program pembinaan mualaf agar anggota mualaf dalam menerima dan melaksanakan ajaran Islam atas dasar kesadaran, kerelaan, dan tidak merasa terpaksa maka relevan menggunakan teori empat prinsip komunikasi persuasif menurut De Vito.

\section{Pengertian Komunikasi Persuasif}

Menurut Burgon dan Huffner dari ringkasan beberapa pendapat ahli mengenaii komunikasi persuasif adalah komunikasi yang bertujuan mempengaruhi pendapat, ide, keyakinan dan sikap orang lain agar orang tersebut mengikuti maksud dari komunikator berdasarkan pada kerelaan dirinya sendiri tanpa merasa terpaksa. ${ }^{21}$

19 Tasmara, Komunikasi Dakwah., 37.

20 lbid., 38.

21 Maulana dan Gumelar, Psikologi Komunikasi., 8.

22 Ibid., 9.
Persuasi adalah kegiatan psikologis artinya komunikator saat berkomunikasi dengan komunikan berdasarkan pada pendasaran yang logis atau pemberian argumentasi yang bisa dipertanggungjawabkan serta alasanalasan psikologis. ${ }^{22}$ Lawan kata dari persuasif adalah memaksa, terror, boikot, pemerasan, penyuapan dan sebagainya untuk bersikap atau berprilaku seperti yang diharapkan oleh komunikator.

\section{Unsur-Unsur Komunikasi Persuasif}

Ada enam unsur-unsur komunikasi persuasif. ${ }^{23}$ Pertama, persuader, yaitu subyek penyampai pesan dengan tujuan untuk mempengaruhi pendapat, pemikiran serta perilaku komunikan dengan komunikasi yang ia sampaikan. Dalam komunikasi persuasif kredibilitas persuader benar-benar sangat dibutuhkan dalam proses komunikasi agar komunikan percaya dan mau menerima keberadaan persuader sebagai penyampai pesan.

Kedua, persuadee adalah orang yang menjadi sasaran atau orang yang dikenai tujuan dari komunikator. Ketiga, pesan, Isi pesan persuasif juga perlu diperhatikan karena isi pesan persuasif kata dan kalimat yang memiliki makna baik verbal maupun non verbal untuk dapat mempengaruhi ide, gagasan, sikap serta keyakinan komunikan atau membuat pengubahan tanggapan sasaran. ${ }^{24}$ Keempat, saluran, yaitu merupakan perantara diantara komunikator saat berkomunikasi dengan komunikan, bentuk

\footnotetext{
23 Ibid.,12.

24 Onong Uchjana Effendy, IImu, Teori dan Filsafat Komunikasi, (Bandung: PT. Citra Aditya Bakti 2007), 43.
} 
saluran komunikasi sesuai dengan jenis komunikasi yang dilakukan. ${ }^{25}$ Kelima, umpan balik. Umpan balik adalah respon atas komunikasi yang dilakukan antara komunikator dan komunikan. Umpan balik ini terjadi pada komunikasi yang sifatnya dua arah, komunikator akan memberikan respon atas pesan yang disampaikan, respon persuader ini disebut umpan balik internal. Sedangkan umpan balik eksternal adalah respon persuadee atas pesan yang disampaikan persuader. $^{26}$ Keenam, efek komunikasi persuasif. Efek komunikasi persuasif hasil dari proses komunikasi antara persuader dengan. Perubahan sikap, pendapat dan tingkah laku adalah bentuk dari efek komunikasi. ${ }^{27}$

\section{Empat Prinsip Komunikasi Persuasif}

Menurut De Vito mengungkapkan dengan menggunakan prinsip-prinsip persuasif dalam berkomunikasi maka akan memudahkan komunikator dalam memperkuat atau mengubah ide, keyakinan, sikap serta prilaku komunikan. Empat prinsip komunikasi persuasif terdiri dari, pertama, prinsip pemaparan selektif (selective exposure principle). Prinsip hukum pemaparan selektif menernagkan bahwa komunikan secara aktif mencari informasi untuk memperkuat pemikiran, sikap dan perilakunya serta secara pasif mencari informasi yang bertentangan dengan apa yang ia yakini. Prinsip pemaparan selektif sangat penting jika komunikator ingin menyakinkan komunikan yang memiliki

\footnotetext{
25 Maulana dan Gumelar, Psikologi Komunikasi dan Persuasi (Jakarta: Akademia Permata 2013), 12.

26 Ibid.

$27 \mathrm{lbid}$.
}

pandangan, pilihan, serta sikap yang berbeda dengan maksud komunikator.

Pemaparan selektif akan terjadi dan berlangsung secara induktif. Misalnya komunikator ingin menyampaikan salah satu cara meningkatkan kualitas hidup manusia adalah dengan bersekolah. Gagasan komunikator tersebut sesuai pendapat komunikan maka komunikator bisa berkomunikasi dengan menyampaikan tesisnya terlebih dahulu kepada komunikan. Jika komunikan ternyata komunikan tidak sependapat, maka komunikator dalam berkomunikasi bisa dengan menunjukkan bukti-bukti pendukung terlebih dahulu dan belum menyampaikan tesis komunikator sampai akhir komunikasi. ${ }^{28}$

Kedua, prinsip partisipasi khalayak. Prinsip ini menekankan pada keterlibatan komunikan dalam berkomunikasi. Keterlibatan tersebut baik memberikan pendapat, menyimpulkan gagasan yang disampaikan oleh komunikator. Serta komunikan tidak secara pasif dalam menerima informasi yang disampaikan oleh komunikator. Dengan prinsip partisipasi khalayak komunikan akan berproses terlibat aktif dalam memahami alasan dan pendasaran pengetahuan yang ia dapatkan, sehingga dengan prinsip partisipasi khalayak akan memudahkan komunikator dalam mencapai tujuannya. ${ }^{29}$

Ketiga, prinsip inokulasi. Prinsip ini menjelaskan tentang komunikan yang telah

\footnotetext{
28 Joseph Devito, Komunikasi Antar Manusia (Jakarta: Karisma Publishing Group, 2011), 500.

29 lbid.
} 
mengetahui bahwa komunikator sudah berbeda pendapat, keyakinan dengan komunikan. Sehingga pada posisi ini, seorang komunikator perlu merencanakan argumentasi saat berkomunikasi dengan komunikan. Komunikator menyampaikan kontra argumen kemudian menjelaskan kelemahannya sehingga membuat komunikan dengan kesadaran dirinya sendiri memahami kekeliruan atas gagasan, keyakinan serta kepercayaannya selama ini. ${ }^{30}$

Keempat, prinsip besaran perubahan. Prinsip ini menyampaikan bila komunikator ingin menginginkan perubahan besar dan penting kepada komunikan maka semakin besar pula tantangan dan tugas komunikator dalam mencapai tujuan persuasi. Manusia berubah secara bertahap, maka efektifnya persuasii bila komunikator dalam berkomunikasi dengan komunikan dengan melakukan perubahan kecil dan dilakukan dalam kurun waktu yang cukup lama. ${ }^{31}$

Semisal dicontohkan komunikator ingin merubah seorang perempuan yang memiliki berat badan yaitu $80 \mathrm{~kg}$, dan turun menjadi 60 kg. Persuasi akan lebih mudah bila mencapai tujuan tersebut dengan menetapkan perubahan kecil terlebih dahulu. Semisal komunikan melakukan diet salah satunya ia harus mengurangi karbohidrat. Namun kondisi anak perempuan tersebut memiliki hobi makan dan tidak tahan lapar. Maka perubahan kecil yang komunikator lakukan adalah menyuruh anak perempuan tersebut bukan tidak boleh makan nasi. Melainkan boleh makan nasi dengan porsii tidak banyak

30 Ibid., 502. dari sebelumnya serta kurun waktu yang kita berikan kepada anak perempuan tersebut untuk bisa mencapai target penurunan berat badan adalah dalam kurun waktu yang lama semisal penurunan berat badan selama dua bulan adalah $1 \mathrm{~kg}$. Perubahan kecil ini akan lebih memudahkan kepada anak perempuan tersebut dibandingkan dengan perubahan besar yaitu melarang untuk makan nasi, namun diganti dengan makanan diet yang lainnya yang membuat berat badan tidak naik namun turun. Serta waktu yang diberikan untuk penurunan berat badan dengan waktu yang singkat artinya dalam waktu satu bulan harus turun $5 \mathrm{~kg}$. Sehingga dengan perubahan besar dengan waktu yang singkat akan menyulitkan komunikator dalam mencapai tujuan persuasi. Karena manusia berubah secara bertahap.

\section{Metodologi}

Studi ini adalah studi kualitatif deskripstif. Mendeskripsikan bagaimana komunikasi persuasif yang dilakukan oleh pembina muallaf Lembaga Dakwah Muhtadin dalam menjalankan program pembinaan muallaf dalam aspek akidah. Sedangkan teknik penggalian data menggunakan wawancara tidak terstruktur. Terdapat dua jenis data, yaitu data primer, dari informan pertama Drs. H. Ach. Zawawi Hamid selaku pembina dan instruktur mualaf bidang Ibadah, Informan kedua yaitu Ir. H. Anang Misbahul Munir selaku pembina dan instruktur mualaf bidang Akidah, informan ketiga Dra. Silvia selaku pembina dan instruktur bidang Ibadah. Sedangkan data sekunder yaitu dokumentasi atau arsip program pembinaan mualaf baik itu

$31 \mathrm{lbid}$. 
handbook anggota mualaf, materi pada saat forum pembinaan mualaf, materi sebagai pegangan Pembina mualaf, selebaran atau brosur perihal kegiatan program pembinaan mualaf, serta buku bacaan yang menjadi referensi anggota mualaf Lembaga Dakwah Muhtadin Masjid Al Falah Surabaya. Informan dalam studi ini dijelaskan pada tabel 1.

Tabel 1 - Identitas Informan Studi

\begin{tabular}{|c|c|c|}
\hline Nama Informan & Kedudukan & Kriteria \\
\hline $\begin{array}{l}\text { Drs. H. Ach. } \\
\text { Zawawi Hamid }\end{array}$ & $\begin{array}{l}\text { Pembina /instruktur } \\
\text { mualaf bidang } \\
\text { lbadah }\end{array}$ & $\begin{array}{l}\text { - Penanggung jawab semua program pembinaan mualaf } \\
\text { baik bidang akidah dan ibadah. } \\
\text { - Pihak yang mengetahui proses pelaksanaan program } \\
\text { pembinaan mualaf dan efek dari program pembinaan } \\
\text { mualaf. }\end{array}$ \\
\hline $\begin{array}{l}\text { Ir. H. Anang } \\
\text { Misbahul Munir }\end{array}$ & $\begin{array}{l}\text { Pembina/Instruktur } \\
\text { mualaf bidang } \\
\text { Akidah }\end{array}$ & $\begin{array}{l}\text { - Instruktur yang menyampaikan materi akidah di forum } \\
\text { pembinaan mualaf. } \\
\text { - Pembina mualaf yang memecahkan persoalan mualaf } \\
\text { dalam bidang akidah. }\end{array}$ \\
\hline Dra. Silvia & $\begin{array}{l}\text { Pembina/Instruktur } \\
\text { bidang Ibadah }\end{array}$ & $\begin{array}{l}\text { - Instruktur yang menyampaikan materi ibadah di forum } \\
\text { pembinaan mualaf. } \\
\text { - Pembina mualaf yang memecahkan persoalan mualaf } \\
\text { dalam bidang ibadah. }\end{array}$ \\
\hline
\end{tabular}

Analisis data menggunakan model Miles dan Huberman yaitu data reduction, data display, dan conclusion drawing/verification. ${ }^{32}$ Data yang diperoleh dari wawancara kepada narasumber yaitu pembina sekaligus instruktur mualaf sehingga mendapatkan data yang sesuai dengan kategori data yang diinginkan yaitu komunikasi persuasif. Kemudian data akan disajikan dalam uraian singkat berdasarkan kategorisasi setelah itu ditarik kesimpulan.

\section{Profil Lembaga Dakwah Muhtadin Masjid Al Falah Surabaya}

Setiap lembaga dakwah harus memiliki visi organisasi. Visi organisasi adalah tujuan

\footnotetext{
32 Sugiyono, Metode Penelitian Kuantitatif, Kualitatif,
} dan R\&D, (Bandung: Alfabeta, 2012), 246. utama atau tujuan jangka panjang yang ingin dicapai di masa depan. Sehingga dengan organisasi memiliki visi maka memudahkan dalam melangkah, karena bila lembaga dakwah tidak memiliki visi organisasi maka mereka akan berjalan secara alamiah dan tidak tentu arah. Sehingga untuk mengukur keberhasilan lembaga dakwah dalam mencapai tujuan dakwah akan kesullitan. Visi organisasi itulah yang dijadikan tujuan utama bagi lembaga dakwah sebagai pijakan dalam menyusun misi dan program-program yang bermanfaat bagi masyarakat.

Begitupun juga Lembaga Dakwah Muhtadin Masjid Al Falah Surabaya dalam menjalankan tugas dakwahnya. Lembaga dakwah tersebut memiliki visi organisasi. Sehingga ada arah 
atau pandangan untuk melangkah di masa yang akan datang dan hasil yang diperoleh dalam pencapaian kegiatan dakwah ada titik tolak ukurannya.

Lembaga Dakwah Muhtadin bergerak di bidang pembinaan kepada para mualaf. Pembinaan adalah upaya pembina melakukan bimbingan dan memberikan arahan kepada obyek yang dibina untuk mencapai tujuan tertentu. Lembaga Dakwah Muhtadin melakukan bimbingan dan memberikan arahan dan bimbingan kepada mualaf untuk mencapai tujuan tertentu. Tujuan tertentu tersebut didasarkan pada kondisi dan latar belakang mualaf sendiri sebagai orang yang masuk Islam. Secara pengetahuan dan pemikiran terhadap agama Islam masih perlu dibimbing dan diarahkan. Secara psikologis juga perlu diberikan motivasi agar semangat dan tetap istiqomah dalam belajar ilmu agama Islam. Mualaf ketika di masa awal berpindah ke agama Islam, tidak sedikit yang mendapatkan tantangan baik dari lingkungan maupun di keluarga.

Maka dari itu Lembaga Dakwah Muhtadin memiliki visi yaitu memberikan pelayanan serta memberdayakan Muhtadin menuju Islam yang Kafah. ${ }^{33}$ Lembaga dakwah dalam mencapai visi organisasi perlu misi. Misii organisasi adalah langkah atau penjabaran yang dibutuhkan dalam mewujudkan visi organisasi. Bentuk konkrit langkah atau penjabaran tersebut adalah penyusunan target atau tujuan jangka pendek dalam kurun waktu tertentu. Dalam rangka untuk

\footnotetext{
${ }^{33}$ Syaifuddin dan Setyawan dkk., 35 Tahun Yayasan, 203.
}

mencapai misi organisasi perlu program kerja. Program kerja inilah sebagai bentuk implementasi pencapaian misi organisasi.

Lembaga Dakwah Muhtadin Masjid Al Falah Surabaya dalam mencapai visi lembaganya yaitu menjadikan para muhtadin menuju Islam Kaffah. Maka dalam mencapai visi tersebut butuh misi dan program. Program Lembaga Dakwah Muhtadin yang pertama adalah memberikan bimbingan kepada muhtadin dalam menjalankan rukun islam yang pertama yaitu menjalankan ikrar masuk Islam. Mualaf diberikan arahan dan bimbingan dalam mengucapkan syahadat. Kedua, setelah mualaf sudah berikrar masuk islam maka perlu adanya usaha dakwah yaitu memberikan bimbingan, pengetahuan tentang agama Islam baik di bidang akidah maupun ibadah serta membaca Alquran. Mualaf adalah orang yang baru masuk Islam, pengetahuan agama Islam perlu dilakukan pembinaan oleh pembina mualaf Lembaga Dakwah Muhtadin agar mualaf menjalankan perintah agama Islam dan menjauhi larangan Allah SWT. Sehingga menjadikan mualaf menjadi muslim yang beriman dan bertaqwa. Ketiga, mualaf setelah masuk Islam, tidak jarang mereka mendapatkan tantangan baik dari lingkungan, keluarga maupun dirinya sendiri dalam menimba agama Islam. Maka dari itu butuh sebuah program yang bersifat konsultasi yang memberikan arahan pemecahan masalah yang dihadapi oleh mualaf dalam memasuki kehidupan barunya yaitu memeluk agama Islam. ${ }^{34}$

34 Syaifuddin dan Setyawan dkk., 35 Tahun Yayasan., 196. 
Program ikrar masuk Islam pada calon muhtadin Masjid Al Falah maka perlu persyaratan yaitu harus mengenal personalitas dari orang yang menerima hidayah Allah tersebut atau calon muhtadin serta informasi identitas orang tua dan kerabat dekat calon muhtadin. ${ }^{35}$ Bahwa pengenalan biodata calon muhtadin penting baik nama, asal mula agama, motivasi masuk Islam dan sebagainya sehingga ini menjadi asumsi atau data yang bisa digunakan oleh pembina mualaf dalam menjalankan program pembinaan mualaf. Semakin pembina mualaf mengenal dan memahami biodata dan seluk beluk calon muhtadin akan memudahkan pembina mualaf dalam menjalankan program pembinaan untuk menjadikan mualaf menuju Islam yang kafah.

Program pembinaan akidah Islam kepada mualaf yang sudah melakukan ikrar masuk Islam. Mualaf diberikan pengetahuan serta arahan dalam mempelajari ajaran agama Islam. Mulai dari mengenal Ketuhanan dalam Islam, kewajiban-kewajiban yang harus dilaksankan sebagai seorang muslim serta mempelajari larangan yang harus ditinggalkan sebagai seorang muslim bersumber pada Alquran dan Hadis. ${ }^{36}$

Program bimbingan salat meliputi hal-hal yang harus (wajib) dipahami, dimengerti, diperhatikan, dan diamalkan sebelum melaksanakan salat mulai definisi salat, kedudukan salat, syarat-syarat salat, syarat sahnya salat, perlunya khusyuk dalam salat, perlunya khusyuk dalam salat, manfaat yang

$35 \mathrm{lbid}$.

36 lbid.,206. didapat dari salat, bahayanya muslim tidak salat, hal-hal yang harus (wajib) diperhatikan, dipahami, dan dimengerti saat melaksanakan salat. $^{37}$

\section{Proses Komunikasi Persuasif Program Pembinaan Mualaf}

Studi ini lebih memaparkan terkait komunikasi persuasif pembinaan mualaf dalam bidang akidah Lembaga Dakwah Muhtadin Masjid Al Falah Surabaya.

\section{Tujuan Program Pembinaan Mualaf}

Tujuan program pembinaan mualaf yaitu menjadikan para mualaf menjadi muslim yang kafah atau Islam yang kafah. Bahwa mualaf adalah orang yang baru masuk Islam. Ia mendapatkan hidayah oleh Allah SWt untuk masuk Islam dan mempelajari agama Islam. Pemikiran mualaf terhadap ajaran Islam perlu untuk diberikan arahan dan bimbingan. Agar mualaf menjadi seseorang yang beriman dan bertaqwa. Sehingga dari sini tujuan program pembinaan mualaf adalah menjadikan mualaf menjadi muslim yang kafah atau Islam yang kafah. Artinya saat mualaf masuk kedalam agama Islam ia harus menyeluruh, mempelajari ajaran agama Islam secara mendalam dan sungguh-sungguh dan berkomitmen untuk menjadi Muslim yang taat dalam menjalankan ajaran agama Islam yang bersumber dari Alquran dan Hadis. Ustaz Zawawi menjelaskan, "Islam yang kafah adalah dalam mempelajari ajaran Islam bersumber dan sesuai dengan Alquran dan Hadis, yaitu akidah yang memiliki tauhid yang kuat dan kokoh, keimanan yang murni. Ibadah

37 Ibid.,207. 
yang benar sesuai dengan apa yang dituntunkan Nabi, kepribadian yang berakhalaqul karimah, karimah itu artinya yang mulia yang luhur." 38

\section{Unsur-unsur Komunikasi Persuasif}

Pertama, pembina mualaf ada tiga orang yaitu, Drs. H. Ach. Zawawi Hamid selaku instruktur di bidang ibadah, Ir. H. Anang Misbahul Munir selaku Instruktur di bidang akidah, dan Dra. Silvia selaku instruktur di bidang ibadah. Pembina mualaf adalah ujung keberhasilan dalam melaksanakan program pembinaan mualaf karena beliau adalah subyek yang memberikan arahan,bimbingan serta pemecahan masalah bagi mualaf baik dalam bidang memberikan arahan dalam menjalankan ajaran agama Islam dan juga pemecahan masalah di kehidupan sehari-hari yang dihadapi mualaf dalam menjalani kehidupan baru yaitu menjadi muslim yang taat kepada Allah SWT. Maka dari itu perlu standart pembina mualaf, dengan kriteria tersebut diharapkan kredibilitas pembina mualaf dalam menjalankan program pembinaan mualaf tidak diragukan sehingga menjadikan mualaf menjadi Islam kafah akan tercapai.

Adapun standart pembina mualaf antara lain karena pembina mualaf ini memiliki tugas untuk memberikan arahan, bimbingan kepada mualaf tentang pemahaman agama Islam maka standart yang pertama adalah pembina mualaf memiliki pemahaman agama Islam. Kedua pembina mualaf adalah lulusan pendidikan S1. Ketiga beliau memahami

38 Ach. Zawawi Hamid, Wawancara oleh Penulis, Surabaya, 26 April 2017.

39 lbid. psikologi komunikasi, artinya pembina mualaf dalam berkomunikasi dengan mualaf dengan mempertimbangkan aspek psikologi baik mempertimbangkan aspek pikiran, perasaan, kebutuhan, serta nilai-nilai yang dimiliki mualaf sehingga tujuan komunikasi akan mudah tercapai. Keempat, Mualaf saat masuk ke dalam agama Islam, juga mendapatkan tantangan baik dari lingkungan, keluarga dan dirinya sendiri dalam bersungguh-sungguh dalam belajar agama Islam, maka perlu layanan konsultasi dalam hal pemecahan masalah pembina mualaf kepada mualaf. Konseling tersebut juga membutuhkan waktu, maka kesediaan pembina mualaf dalam menyediakan waktu untuk melakukan konseling kepada mualaf menjadi pertimbangan atau kriteria. Keempat pembina mualaf bisa memberikan contoh, bahwa apa yang disampaikan oleh pembina mualaf juga seharusnya diterapkan juga oleh pembina mualaf.

Terkait hal tersebut, Ustaz Zawawi menuturkan, "Yang pertama karena materi yang disampaikan adalah agama, sehingga memiliki pemahaman agama Islam, yang kedua bahwa teman-teman mualaf adalah beragam tingkatan pendidikannya, ada yang tidak berpendidikan, ada yang berpendidikan ada yang SD, ada yang SMP, SMU, Sarjana dan ada yang S2. ada yang sudah Doktor oleh karena itu teman-teman Pembina di Muhtadin ini minimal S1. ${ }^{139}$ Sedangkan Ustaz Anang menambahkan, "Harus memahami psikologi komunikasi, karena problem mualaf itu tidak bisa di selesaikan hitam putih. ${ }^{\prime 40}$

${ }^{40}$ Anang Misabhul Munir, Wawancara oleh Penulis, Surabaya, 27 April 2017. 
Ustazah Silvia menambahkan, "Pembina mualaf tidak hanya siap dan siaga memberikan bimbingan dan arahan saat mengajar saja, melainkan pembina mualaf juga siap dan siaga dalam memberikan layanan konseling kepada mualaf setiap saat dan setiap waktu yang dibutuhkan oleh mualaf ketika menghadapi permasalahan".

Bisa menjadi contoh, jadi apa yang pembina mualaf ajarkan kepada mualaf, pembina mualaf juga mengamalkannya. ${ }^{n 1}$

Kedua, persuade, dalam hal ini adalah anggota mualaf. Jumlah anggota mualaf rata-rata per tahun kisaran 180-200 orang. Mereka yang mau masuk Islam, akan melakukan pembinaan mualaf selama tiga bulan.

Ketiga, materi pembinaan mualaf. Materi pembinaan mualaf ada dua yaitu materi ibadah dan materi akidah. Materi ibadah mengajarkan kepada para mualaf bagaimana cara mudah untuk membaca teks Alquran materi thaharah materi pemahaman tentang batalnya salat, wudhu, dan tayamum, materi tentang salat, serta doa dan zikir. ${ }^{42}$ Sedangkan materi akidah adalah pembinaan perihal akidah Islam meliputi: (a) pemahaman umum tentang Islam mulai definisi tentang Islam, sumber nilai Islam, karakteristik Islam, ruang lingkup ajaran Islam, kewajiban muslim terhadap Islam; (b) rukun Iman (c) Ketuhanan (d) Alquran dan Hadis, mulai dari kedudukan Alquran dan Hadis, pokok-pokok Alquran dan Hadis, karakteristik muslim terhadap Alquran dan Hadis, kewajiban muslim terhadap Alquran dan Hadis; (e) ibadah. Keempat, yaitu

${ }^{41}$ Silvia, Wawancara oleh Penulis, Surabaya, 26 April 2017. media yang digunakan oleh pembina mualaf dalam menyampaikan materi dengan media papan tulis, hand out atau buku pegangan.

\section{Proses Komunikasi Persuasif Program Pembinaan Mualaf di Bidang Akidah}

Proses komunikasi persuasif yang dilakukan pembina mualaf di bidang akidah adalah bagaimana komunikasi yang dilakukan oleh pembina mualaf dalam menyampaikan materi akidah kepada mualaf didasarkan pada kesadaran sendiri. Sehingga mualaf dalam menjalankan dan mengamalkan materi tersebut atas dasar keinginan dan kemauan dirinya sendiri tanpa merasa dipaksa atau diancam oleh orang lain.

Pembina mualaf dalam menyampaikan materi akidah kepada mualaf pada forum pembinaan mualaf menggunakan cara yaitu sebelum forum pembinaan akidah dimulai, para mualaf diberikan tugas dirumah yaitu membuat catatan pertanyaan yang akan diajukan sebelum kegiatan pembinaan mualaf dimulai. Jadi sebelum instruktur atau pembina mualaf menyampaikan materi akidah, ada sesi mualaf sebagai peserta mengajukan pertanyaan kepada instruktur. Sumber pertanyaan mualaf bisa berbagai macam variasi, pertanyaan yang diajukan bisa dari pengamatan mualaf di kehidupan keseharian. Pengalaman pribadi mualaf yang masih tekateki sehingga persoalan tersebut butuh solusi dari orang lain, sehingga bisa menjadi pertanyaan yang diajukan kepada pembina mualaf. Diskusi dengan teman kantor tentang ajaran agama Islam, yang masih butuh kroscek

${ }^{42}$ Ach. Zawawi Hamid, Materi Ibadah (Surabaya, Muhtadin Masjid Al-Falah) 
pemahaman dan butuh jawaban dari pembina mualaf sehingga bisa menjadi pertanyaan yang diajukan kepada pembina mualaf.

Contohnya pada forum pembinaan akidah, ada salah satu salah satu anggota mualaf mengajukan pertanyaan kepada pembina mualaf, pertanyaan tersebut bersumber darii pengamatan mualaf melihat fenomena di lingkungan kehidupan seharinya perihal keyakinan Tuhan sebagai Zat Pencipta, ada dialektika di dalam pemikiran mualaf yaitu sebab Allah menciptakan alam semesta dan manusia. Sehingga hasil dialektika pemikiran tersebut butuh sebuah bimbingan dan arahan kepada pembina mualaf agar mualaf mendapatkan jawaban yang tepat. Sehingga salah satu cara yang dilakukan oleh pembina mualaf adalah memberikan kesempatan kepada mualaf untuk mendata pertanyaan sebelum forum pembinaan akidah dimulai. ${ }^{43}$

Kegiatan pembinaan mualaf secara durasi kisaran satu jam tiga puluh menit. Kegiatan pembinaan mualaf berisikan penjawaban pertanyaan para mualaf. Mualaf diberikan kesempatan terlebih dahulu untuk mengajuakn pertanyaan yang sudah disiapkan sebelumnya. Dalam forum pembinaan mualaf berlangsung semua para mualaf aktif dalam memberikan pertanyaan kepada pembina mualaf baik laki-laki maupun perempuan. ${ }^{44}$

Selain itu instruktur menggunakan metode debat dan diskusi. Metode diskusi adalah komunikasi dua arah yang dilakukan oleh pembina mualaf dengan mualaf untuk bertukar pendapat, pemikiran, pengalaman

43 Ibid. untuk mendapatkan kesepakatan dalam usaha pemecahan masalah yang dihadapi. Bahan diskusi perihal masalah akidah missal ada keluarga mualaf yang menyimpan dan mengkeramatkan keris. Kemudian pembina mualaf berdiskusi dengan mualaf terkait dengan keris itu apa menurut ajaran agama Islam dan seharusnya sikap dan prilaku kita bagaimana ketika dihadapakn dengan keluarga yang menyimpan dan mengkeramatkan keris. Serta berdiskusi tentang asal muasal kehidupan dan sebagainya.

Pembina mualaf juga menggunakan metode debat dengan anggota mualaf pada forum pembinaan mualaf, pembina mualaf melakukan adu argumentasi dengan anggota mualaf untuk mencari kebenaran. Konteks penggunaan metode debat yang dilakukan oleh pembina mualaf ketika anggota mualaf sulit dalam menerima masukan pembina mualaf. Pada saat itu ada salah satu anggota mualaf yang pekerjaannya tidak sesuai dengan norma Islam. Jadi anggota mualaf tersebut memiliki usaha panti pijat kemudian ada karyawannya yang memberikan pelayanan pijat plus sehingga usahanya semakin ramai, dan anggota mualaf tersebut membiarkannya padahal ini tidak sesuai dengan norma islam. Pada saat itu pembina mualaf mengingatkan kepada anggota mualaf yang selaku pemilik usaha panti pijat bahwa karyawan yang membuka layanan panti pijat plus ini tidak sesuai dengan norma islam. Namun anggota mualaf tersebut menjawab bahwa ia tidak terlibat dan tidak ikut-ikutan melainkan itu adalah urusan pegawainya, dan

${ }^{44}$ lbid. 
anggota mualaf juga menyampaikan bahwa ia juga tidak memfasilitasinya. Proses komunikasi dengan metode debat yang dilakukan oleh pembina mualaf dengan anggota mualaf tersebut cukup panjang. Kemudian dijawab oleh pembina mualaf "namun anda yang memfasilitasi tempat itu". ${ }^{45}$ Artinya anggota mualaf sudah tahu dan membiarkan karyawannya membuka panti pijat plus dan prilaku ini bertentangan dengan norma islam, sehingga anggota mualaf turut andil untuk mengiyakan usaha tersebut

Proses diskusi dalam memecahkan persoalan yang dihadapi oleh mualaf seperti paparan di atas yakni pembina mualaf menyakinkan dengan memberikan cerita anak salah asuhan. Dikisahkan pada zaman Nabi, pada saat nabi sedang rapat kemudian ada salah satu anak yang masuk dan tidak mengucapkan salam. Anak tersebut langsung mengambil bola ditengah rapat. Setelah itu Nabi menyampaikan bahwa anak ini salah asuhan. Kemudian orang tua anak tersebut yang juga ikut dalam rapat tersebut mendengar perkataan Nabi. Dan suami lantas menanyakan kepada istrinya bagaimana mendidik anaknya. Kemudian istripun tidak diterima karena disalahkan sehingga suami dan istri tersebut bertengkar. Pertengakaran tersebut didengar oleh Nabi. Akhirnya Nabi memanggil kedua orang tua tersebut dan bertanya apa saja yang diajarkan orang tua kepada anaknya. Namun kedua orang tua tersebut menjawab bahwa mereka mengajarkan hal kebaikan kepada anaknya. Namun Nabi menyuruh kepada kedua orang tua tersebut untuk mengingat-ingat apa yang

$45 \mathrm{Ibid}$. dilakukan oleh istri pada masa kehamilan. Setelah itu kedua orang tua tersebut sadar bahwa suaminya pernah mencuri anak kambing orang lain lalu menyembelihnya dan memberikan kepada istri, karena saat itu si istri sedang menginginkan makan anak kambing sedang si suami tidak memiliki uang. Setelah itu Nabi menyampaikan bahwa kejadian tersebut adalah pendidikan anak pada saat di dalam kandungan yaitu memberikan makanan yang bersumber dari yang haram sehingga membuat anak berprilaku tidak baik. ${ }^{46}$ Setelah pembina mualaf menyampaikan cerita anak salah asuhan kepada anggota mualaf tersebut, respon mualafpun menangis.

Komunikasi yang dilakukan pembina mualaf selain menggunakan metode diskusi dan debat, pembina mualaf juga memberikan kesempatan kepada mualaf untuk berfikir atau berdialektika. Pembina mualaf memberikan sebuah argumentasi yang berisikan data-data perihal seputar pertanyaan mualaf. Sehingga dari data tersebut mualaf berusaha aktif untuk mencari jawaban sendiri atas pertanyaan tersebut baru kemudian pembina mualaf menyampaikan tesisnya.

Dalam proses komunikasi program pembinaan mualaf, banyak perubahan yang didapat oleh anggota mualaf. Pertama, tingkat prosentase mualaf yang balik ke agama asal rendah. Kedua, mereka tidak menjalankan syirik, kurafat dan takhayul. Ketiga, mereka menjalankan salat sesuai dengan sunnah Nabi dan Rasul, dan itupun

${ }^{46} \mathrm{lbid}$. 
juga diamini oleh anggota mualaf. Hasil wawancara dengan mualaf juga menunjukkan bahwa mereka ada perubahan mulai cinta untuk menimba ilmu agama Islam, juga ada perubahan mulai menggunakan jilbab dan menjalankan perintah agama Islam.

\section{Analisis Komunikasi Persuasif Program Pembinaan Mualaf di Bidang Akidah}

Proses komunikasi persuasif program pembinaan mualaf di bidang akidah, pertama yaitu anggota mualaf diberikan arahan untuk mempersiapkan pertanyaan-pertanyaan yang akan diajukan sebelum kegiatan pembinaan mualaf berlangsung. Seperti salah satu anggota mualaf yang melakukan pengamatan fenomena di lingkungan kehidupan seharinya perihal keyakinan Tuhan sebagai Zat pencipta, kenapa Allah menciptakan alam semesta dan manusia yang pada akhirnya alam semesta dan manusia akan mengalami kerusakan. Hasil pengamatan fenomena tersebut kemudian ditanyakan kepada pembina mualaf. Kemudian pembina mualaf berusaha untuk menyakinkan kepada mualaf tersebut agar memiliki sikap yang sama dengan komunikator dengan pola induktif artinya pembina mualaf menyampaikan fakta dan bukti setelah itu menyampaikan kesimpulan atau maksud komunikator tersebut.

Fenomena yang demikian menunjukkan bahwa komunikasi persuasif yang dilakukan pembina mualaf sudah sesuai hukum pemaparan selektif, yaitu mualaf akan secara aktif mencari informasi yang mendukung pemikiran atau pandangan mereka mulai dari melihat realitas dikehidupan sehari mereka dan secara aktif menghindari informasi yang bertentangan pemikiran atau pandangan mereka.

Pemaparan selektif terjadi dan berlangsung secara induktif yaitu khusus kemudian ke umum manakala komunikator ingin menyakinkan komunikan yang memiliki sikap yang berbeda dengan komunikator. Sehingga komunikator akan menyampaikan bukti dan argumen terlebih dahulu kemudian kesimpulan atau maksud yang diharapkan oleh komunikator. Pembina mualaf berusaha menyakinkan kepada mualaf dengan menggunakan pola induktif artinya pembina mualaf menunjukkan fakta dan bukti untuk menyakinkan kepada salah satu anggota mualaf yang memiliki usaha yang bertentangan dengan norma islam, asumsi mualaf tersebut sebelumnya tidak mau mengakui kesalahan apa yang ia lakukan, kemudian pembina mualaf memberikan penjelasan lewat cerita anak yang salah asuhan kemudian anggota mualafpun tersadarkan. Cerita anak yang salah asuhan adalah orang tua yang memberikan makanan kepada anaknya dengan cara yang tidak baik yaitu mencuri. Sehingga ada perilaku yang tidak baik yang dilakukan oleh anak tersebut. Setelah diberikan penjelasan tersebut kemudian mualaf tersebut menangis.

Mualaf akan lebih mudah mencapai tujuan bila menggunakan prinsip pemaparan selektif. Apabila ada perbedaan sikap dan kepercayaan komunikator dan komunikan maka komunikator harus menyakinkan komunikan dengan pola induktif yaitu menunjukkan fakta dan bukti setelah itu kesimpulan atau maksud 
dari komunikator. Dalam menunjukkan fakta dan bukti seharusnya ada pertanggung jawaban yang kuat dengan berpijak pada Alquran, Sunnah dan ilmu pengetahuan terkait. Dengan pemaparan selektif yang dilakukan oleh pembina mualaf kepada mualaf maka tujuan pembentukan Islam kafah akan tercapai.

Kedua, pembina mualaf dalam menyampaikan materi kepada anggota mualaf dengan menggunakan prinsip pasrtisipasi khalayak. Anggota mualaf diberikan kesempatan bertanya menyampaikan pendapat, pemikirannya tekait topik yang menjadi diskusi serta mengajukan pertanyaan yang sudah ia persiapkan dirumah pada forum pembinaan mualaf. Selama pengamatan penulis yang juga terlibat di dalam forum pembinaan mualaf yang durasi waktunya $1.5 \mathrm{jam}$, dan selama itu pula forum pembinaan mualaf dii isi dengan proses tanya jawab pembina mualaf dengan anggota mualaf. Prinsip partisipasi khalayak membuat anggota mualaf selaku komunikan terlibat aktif dalam proses menemukan kebenaran, ada proses dialektika dan proses berifikir mualaf dalam mencari kebenaran. Sehingga anggota mualaf selaku komunikan tidak hanya sekedar menerima secara pasif informasi atau materi yang disampaikan melainkan anggota mualaf juga terlibat berproses, berdialektika dalam proses memahami ajaran agama Islam. Sehingga dengan prinsip partisipasi khalayak pada forum pembinaan mualaf membuat anggota mualaf tidak merasa bosan dan anggota mualaf dalam memahami ajaran agama Islam dengan pendasaran yang kuat, karena mereka terlibat proses tanya jawab dan aktif dalam memahami kebenaran agama Islam. Sehingga komunikator dengan menggunakan prinsip partisipasi khalayak akan memudahkan dalam mencapai tujuan komunikasi persuasi, artinya komunikan akan mengamalkan ajaran agama Islam berdasarkan kesadaran dan kemauannya sendiri.

Ketiga, adanya debat dan diskusi yang dilakukan oleh anggota mualaf dengan pembina mualaf. Hasil pengamatan dalam forum pembinaan mualaf menunjukkan adanya diskusi perihal masalah akidah, misalnya persoalan keluarga yang memiliki benda keramat yaitu misal keris tersebut. Bahkan pembina mualaf dan anggota mualaf juga melakukan debat terutama bilamana anggota mualaf berprilaku yang tidak sesuai dengan norma islam dan anggota mualaf tersebut sulit menerima masukan dari pembina mualaf.

Paparan di atas menunjukkan komunikasi pembina mualaf Lembaga Dakwah Muhtadin memenuhi prinsip hukum partisipasi khalayak. Mualaf selaku komunikan ikut aktif baik lewat bertanya, memberikan pendapat maupun adu argumentasi maka proses kognitif mualaf akan melakukan proses mengolah data baik mencerna, memhami dan melakukan analisis serta kesimpulan untuk memperkuat ide, keyakinan, pilihan dan tindakan komunikan. Sedangkan mereka yang kecenderungan tidak aktif walaupun mereka mendengarkan, proses kognitif tidak akan berjalan dengan optimal karena komunikan hanya menerima pengetahuan itu saja. Sehingga prinsip partisipasi khalayak diterapkan pembina mualaf Lembaga Dakwah 
Muhtadin dalam menjalankan program pembinaan mualaf.

Keempat, proses komunikasi program pembinaan mualaf dibidang akidah. Data menunjukkan mualaf ketika bertanya kepada instruktur, instruktur tidak lantas menjawab atau menyanggah secara langsung. Melainkan mualaf diberikan data dan argumentasi terkait dengan pertanyaan tersebut, kemudian mualaf berusaha berfikir dan menemukan jawaban sendiri.

Seperti kisah yang dipaparkan sebelumnya bahwa ada anggota mualaf yang memiliki usaha panti pijat, namun karyawannya memberikan layanan panti pijat plus dan anggota mualaf tersebut selaku pemilik usaha yang mengetahui karyawannya memberikan layanan pijat plus membiarkan dengan dalih bahwa ia tidak ikut-ikutan padahal prilaku ini bertentangan dengan norma Islam. Kemudian pembina mualaf menyampaikan kisah tentang anak yang salah asuhan pada zaman Nabi, repson mualafpun akhirnya menangis.

Komunikasi pembina mualaf kepada anggota mualaf pada kasus ini memenuhi prinsip inokulasi, bahwa komunikan sudah mengetahui posisi komunikator yang akan menentang pendapat serta keyakinannya. Dalam konteks kasus di atas anggota mualaf mengetahui bahwa pembina mualaf telah menyiapkan argument untuk menentangnya. Sehingga pada posisi ini, seorang komunikator perlu merencanakan komunikasi dalam menjawab pemikiran komunikan dengan menyampaikan kontra argumen dan menunjukkan kelemahan-kelemahan pemikiran komunikan. Sehingga komunikan sadar bahwa selama ini pemahaman yang ia yakini adalah keliru. Artinya lewat kisah anak salah asuhan pada saat zaman $\mathrm{Nabi}$, pembina mualaf telah memberikan kontra argumen serta menunjukkan kelemahan serta letak kekeliruan pemahaman komunikan sehingga membuat pemikiran anggota mualaf terbuka akan kebenaran.

Paparan di atas memenuhi prinsip hukum inokulasi yaitu komunikator menunjukkan kelemahan pemikiran atau argumentasi komunikan sehingga membuat mualaf lebih bisa melakukan dialektika sendiri didalam proses kognitifnya. Sehingga akan membuat pemikiran dan perbuatan mualaf akan kuat terhadap tujuan yang telah ditentukan oleh komunikator yaitu Islam kafah.

Prinsip perubahan besar mengatakan bahwa semakin besar target yang ingin dicapai oleh komunikator maka semakin besar pula usaha yang harus diraih oleh komunikator untuk mencapainya. Sehingga persuasi lebih efektif bila diarahakan pada perubahan dengan target yang kecil dan jangka waktu yang lama. Misal orang yang ingin menguruskan badan, maka perubahan kecil akan lebih mudah dicapai yaitu dengan menguragi porsi makan nasi dari sebelumnya dan durasi penurunan berat badan dalam jangka waktu yang lama. Dibandingkan dengan perubahan dengan target yang besar yaitu tidak boleh makan nasi dan durasi penurunan berat badan dalam waktu yang pendek.

Dalam meneliti perubahan akidah yang terjadi pada setiap mualaf muhtadin membutuhkan waktu yang bervariasi, karena setiap anggota mualaf memiliki latar belakang yang berbeda 
perihal pengetahuan terhadap Islam. Sehingga kurang mendalami di aspek prinsip besaran perubahan karena membutuhkan waktu yang cukup lama.

Tiga prinsip komunikasi persuasif yang dilakukan oleh pembina mualaf baik prinsip komunikasi pemaparan selektif, prinsip komunikasi partisipasi khalayak, prinsip inokulasi telah memberikan efek kepada anggota mualaf antara lain, pertama adalah adanya peningkatan pemahaman dan pegetahuan akidah bagi mualaf. Kedua, perasaan senang, tertarik dalam mengikuti program pembinaan mualaf. Dalam setahun ada kurang lebih 200 orang yang mengikuti program tersebut. Ketiga, ada perubahan sikap dan tingkah laku yang ditampilkan mualaf mulai melaksankan perintah agama baik menjalankan salat wajib, salat tahajud, berpuasa dan bersedekah. Anggota mualaf suda ada prilaku tidal lagi menyimpan dan mengkeramatkan keris di rumah dan ini adalah salah satu tindakan tidak menjalankan perbuatan oleh ajaran agama Islam.

\section{Kesimpulan}

Pembina mualaf dalam menyampaikan materi akidah kepada anggota mualaf sudah memenuhi prinsip komunikasi persuasif. Antara lain prinsip pemaparan selektif yaitu komunikan akan secara aktif mencari pengetahuan yang mendukung ide, gagasan, keyakinan, keputusan dan tindakan komunikan. Serta komunikan akan secara pasif mencari informasi yang bertentangan denga pandangan, pemikiran, sikap dan perilakunya. Pemaparan selektif terjadi dan berlangsung secara induktif manakala komunikator ingin menyakinkan kepada komunikan yang memiliki sikap yang berbeda dengan komunikator. Data menunjukkan pembina mualaf berusaha menyakinkan kepada mualaf yang memiliki sikap yang berbeda dengan komunikator, dengan menggunakan pola induktif artinya pembina mualaf menunjukkan fakta dan bukti kemudian kesimpulan atau maksud dari komunikator. Sehingga Lembaga Dakwah Muhtadin Masjid Al Falah Surabaya menjalankan prinsip pemaparan selektif dalam menerapkan komunikasi program pembinaan mualaf.

Memenuhi prinsip partisipasi khalayak yaitu, komunikan terlibat aktif dalam forum diskusi dan bertanya dengan komunikator. Komunikan tidak pasif dalam menerima informasi atau materi yang disampaikan oleh komunikator sehingga Lembaga Dakwah Muhtadin menjalankan prinsip partisipasi khalayak dalam menjalankan komunikasi program pembinaan mualaf.

Memenuhi prinsip inokulasi yaitu menjelaskan tentang cara menghadapi komunikan yang sudah mengetahui bahwa komunikator akan menyampaikan pesan yang justru berlawanan dengan pandangan, pemikiran serta keyakinan komunikan. Instruktur memberikan kesempatan bagi komunikan untuk melakukan dialektika pemikiran terlebih dahulu dan tidak lantas Instruktur langsung menjawab atau menyanggah argumentasi komunikan. Sehingga Lembaga Dakwah Muhtadin menjalankan prinsip inokulasi pada saat melakukan komunikasi pembinaan mualaf. 
Hasil studi ini diharapkan mampu memberikan inspirasi berbagai lembaga Program pembinaan mualaf Lembaga Dakwah dakwah lainnya untuk berkomunikasi secara Muhtadin selain di bidang akidah islam juga di persuasif kepada mad'uw. Sehingga membuat bidang ibadah dan baca Alquran. Sehingga, pembahasan pesan dakwah menjadi menarik, untuk penelitian berikutnya akan lebih baik menyenangkan dan sesuai kebutuhan mad'uw. Mad'uw akan termotivasi untuk mengaplikasikan ajaran Islam dengan kesadaran tanpa merasa terpaksa. Tulisan ini masih berfokus pada deskripsi komunikasi persuasif pembinaan mualaf Lembaga Dakwah Muhtadin Masjid Al Falah Surabaya dalam bidang akidah.

jika meneliti pola komunikasi pembinaan mualaf Lembaga Dakwah Muhtadin Masjid Al Falah Surabaya di bidang ibadah dan baca Alquran. Mengingat tantangan tersendiri bagi pembina mualaf memberikan bimbingan kepada mualaf agar bisa membaca doa salat dan Alquran.

\section{Bibliografi}

Aprianto, Tri Prasetyo. "Strategi Komunikasi Penyuluhan pada Pembinaan Mualaf di Yayasan AnNaba Center Sawah baru Ciputat." Skripsi, Universitas Islam Negeri Syarif Hidayatullah, 2015.

Bungin, Burhan. Metodologi Penelitian Sosial: Format-Format Kuantitatif Dan Kualitatif. Surabaya: Airlangga University Press, 2011.

Departemen Agama RI Ditjen Bimas Islam dan urusan Haji Proyek Peningkatan Tenaga Keagamaan "Pedoman Pembinaan Mualaf " diakses 16 Januari 2017

http://simbi.kemenag.go.id/pustaka/images/materibuku/Pedoman\%20Pembinaan\%20Mual af.pdf.

Desyafitri, Maike. "Komunikasi persuasif komunitas hijabers pekanbaru dalam merekrut wanita berjilbab di kota pekanbaru." JOM FISIP, Vol. 2 No. 1 (Februari 2015)

Devito, Joseph A. Komunikasi Antar manusia, Edisi Kelima. Jakarta: Karisma Publishing Group, 2011. Effendy, Onong Uchjana. IImu, Teori dan Filsafat Komunikasi. Bandung: PT Citra Aditya Bakti, 2003. Hakiki, Titian dan Rudi Cahyono, "Komitmen Beragama pada Mualaf: Studi Kasus pada Mualaf Usia Dewasa." Jurnal Psikologi Klinis dan Kesehatan Mental, Vol. 4. No.1 (April 2015).

Hakim, Ramlah. "Pola Pembinaan Mualaf di Kabupaten Sidrap Provinsi Sulawesi selatan." Jurnal AlQalam, Vol. 19, No.1 (Juni 2013).

Maulana, Herdiyan dan Gumgum Gumelar. Psikologi Komunikasi dan Persuasi. Jakarta: Akademia Permata, 2013.

Nurhalima, "Komunikasi Persuasif Majelis Tabligh Pimpinan Daerah Aisyiyah dalam Meningkatkan Akidah Islam di Kabupaten Karo Sumatera Utara." Tesis, IAIN Medan, 2013.

Rahmi, Washilatur. "Bentuk Komunikasi Pembinaan Mualaf daarut Tauhid Jakarta." Skripsi, Universitas Islam Negeri Syarif Hidayatullah, 2008. 
Republika, "Dialog 1, 5 Jam, Galih Putuskan Menjadi Muslim" republika.co.id. 11 mei 2018. http://khazanah.republika.co.id/berita/dunia-Islam/mualaf/15/01/30/nizjx5-dialog-15-jamgalih-putuskan-menjadi-muslim.

Republika, "Lima Tahun Terakhir, Ada 10 ribu Orang Masuk Islam," Repubika.co.id. 9 mei 2018. http://republika.co.id/berita/dunia-Islam/Islam-nusantara/17/02/01/okpetz394-lima-tahunterakhir-ada-10-ribu-orang-masuk-Islam.

Sugiyono, Metode Penelitian Kuantitatif, Kualitatif, dan R\&D. Bandung: Alfabeta, 2012.

Syaifuddin, Djuari dan Rustanto setyawan dkk., 35 Tahun Yayasan Masjid Al Falah Surabaya: Sejarah Singkat Dan Sekilas Perkembangan. Surabaya: Yayasan Masjid Al Falah, 2008.

Tasmara, Toto. Komunikasi Dakwah. Jakarta: Penerbit Gaya Media Pratama, 1997. 
Sri Wahyuni

162 | Jurnal Kajian \& Pengembangan Manajemen Dakwah 